\title{
Assessment of Ecotourism from the Perspective of the Sustainable Development Based on SWOT Model (Case: Azerbaijan Region of Iran)
}

\author{
Saghar Hosseinalizadeh ${ }^{1}$, Sevda Jabbari ${ }^{2}$, Masoud Haghlesan ${ }^{3}$
}

\begin{abstract}
The most important industry in sustainable tourism is ecotourism that contains a deep relationship with the sustainable development. Additionally, majority of countries focus on this connection. In this paper, reviewing theoretical foundations of the sustainable development and ecotourism, using experts' opinions and analyzing the current status of Azerbaijan, Iran has been addressed according to tourist areas in the form of SWOT Table and by assessing all ecotourism and sustainable development indices a relationship between these concepts has been discussed. The conceptual model of the paper is based on "analytical-descriptive" method that has been examined by collecting information and theoretical data from scientific, documented bases, literature study and the research observations. The results indicate a shortage of water resources, ecological changes, environmental pollution, institutions' ignorance, lack of urban services and infrastructure, illegal hunting and low cultural level of people in maintaining and finally increasing rural to urban migration and environmental degradation.
\end{abstract}

Keywords: Ecotourism; Sustainability; Azerbaijan Iran; SWOT model

\section{Introduction and Objective}

The word ecotourism is a relatively recent phenomenon in tourism industry that constitutes only a part of the industry (Nyaupane\&Thapa, 2004:25). Today, extensive studies have been done on ecotourism to visit the natural origins and aimed to protect the cultural heritage as a viable economic alternative. On the one hand, protecting natural and ecological resources as basic principles of ecotourism is related to sustainable development indices closely and directly. What the concepts of the sustainable development refer to: the needs of the future generation to current resources respond to them and make a balance between environmental and economic aspects. Iran to its scope, in terms of the diversity of climate, biodiversity, and beautiful and diverse natural landscapes is evident as an exceptional country in the world (Jahanian \& Zandi, 2013). In Iran, Azerbaijan is considered as one of the main environmental and historical areas. Unfortunately, with people's negligence, failure to devote sufficient budget for investment, guards' inattention, lack of adequate support of related organizations and institutions, adequate training for better understanding has not been provided to the domestic and foreign tourists. Also, the main cause of imbalance in the environment is

\footnotetext{
${ }^{1}$ Departement of Architecture Urban Planning Construction Engineering, Politecnico of Milan University, Milan, Italy

${ }^{2}$ Departement of Urban Planning Engineering (Urbanisim), Faculty of Art \& Architecture, Islamic Azad University, Tabriz, Iran

${ }^{3}$ Assisstmant Professor, Department of Architecture, Ilkhchi Branch, Islamic Azad University, Ilkhchi, Iran
} 
rapid growth of population, all of the mentioned fade the value and the concept of ecotourism in these areas and the importance of this issue is evident in many humanoriented branches and renewable energy. Unfortunately, due to lack of correct prediction of the perspective by governmental and public institutions and the indiscriminate use of natural resources, during several recent decades enough measures have not been done to solve this problem.

Then, some given qualities and factors of ecotourism and sustainable development have been examined in few studies done that in their overview general indices and their factors have not been examined:

In research done on assessing ecotourism from the perspective of the sustainable development in Azerbaijan, Iran based on SWOT model, the results obtained indicate that most of focus has been on indices of ecotourism and sustainable development such as the culture, training and participation in decision-making and identifying natural resources from sustainable development view and political, social, cultural and technological indices of sustainable development have not been referred.

In another research titled assessing ecotourism from the perspective of the sustainable development in Azerbaijan, Iran based on SWOT model researchers using ecological assessment method as the most appropriate method have addressed the needs of planning and hierarchical information and map integration and their achievements have been on the participation of natives and appreciating them for correct identification of the environment. And what has not been well considered in this research is nonallocated positive exchange between tourists and natives, and lack of adequate training that is more an overview of indices of the sustainable development.

In the study titled assessing ecotourism from the perspective of the sustainable development in Azerbaijan, Iran based on SWOT model researchers after analyzing the challenges ahead with the sustainable development of renewable natural resources and achieving objective evidence have found that several species of mammals and plants' structure are becoming extinct. In the research, ecotourism indices such as public participation in decisions, planning and implementation of projects, adequate training for tourists, and the technology index of the sustainable development have not been mentioned.

Showed in Her study that economic and social development of the region and its heritage value are important factor of the sustainable development and affect increasing the collective consciousness to support local ecosystem; and train protecting natural resources to create ecotourism regions and meaningful experiences attending these places are emphasized. From ecotourism view system capacities, respect for social, cultural, traditional structures, the way of life of people and local communities, income and the fair division; and from the perspective of the sustainable development the traffic growth, lack of access to urban service, the movement in socio-cultural index and on the one hand, the distribution of income and per capita of citizens, city management budget of economic and technological index have not been mentioned.(tuba, kipper)

The problem's continuity and disregarding it for a long time will cause environmental crises, the destruction of resources, create resources to reach the sustainable development and failure to properly assess the natural potentials will face future generations with a serious problem of lack of resources. Non-recognition of the natural 
environment capability not only from environmental aspect but also different economic and social aspects brings irreparable damages. Without assessing, recognition and analysis of the environment, related governmental officials and organization exploit these resources improperly that leads to a waste of time, spend huge budgets and achieve undesired results and, most importantly, creating the changes in the environment brings irreparable damages. (Forslid, Haaland \& Midelfart 2002: 273-97)

The significance of this study first is to identify attractions, recreational and tourism activities and provide an appropriate ground for the development of the industry and planning to develop them in the second phase is essential.

What is important is to make motivation for related governmental officials and organizations to identify and assess the environment correctly and its exploitation, natives' familiarity with existing potentials in order to protect them and replace tourism by ecotourism to boost nature tourism. Solve problems caused by environmental crises not only affects socioeconomic and cultural prosperity of communities, but also affects next generations' use, enhance the quality of life and replace renewable sources. The purpose is to identify and assess ecotourism potentials in the region of Azerbaijan with an emphasis on the sustainable development and ecotourism industry boom using the sustainable development indices of natives' participation in the identification and exploitation of the environment and use of low budget to protect resources.

\section{Methodology}

This research method is descriptive-analytic that information has been collected by reading books, reports, papers, and theses, referring to relevant organizations, as well as through the translation of the literature related to the topic including Latin valid papers. Ecotourism assessment basis has been according to indices of the sustainable development using SWOT Table analysis method.

\section{Sustainable Development Meaning}

In explaining the concept of the sustainable development at conferences and meetings held by the United Nations expressions such as cultural sustainable development, agricultural sustainable development, environmental sustainable development, social sustainable development, economic sustainable development and political sustainable development policy have been used that all the components in addition to regarding the economic growth and international competitiveness, have been calculated fairly. Some experts have offered numerous definitions that we will discuss some of them:

1. In a more general definition of the sustainable development as a process, it is improvement and progress requirement, a process that is the basis of the status improvement and removes socio-cultural shortcomings of communities. Also, the sustainable development has been mentioned also as the driving force of balanced, appropriate and coordinated economic, social and cultural development of all countries, particularly developing countries (Salami, 1997: 44).

2. The United Nations Environment Program defined the sustainable development as 
the progress (the quality of life with regard to the provision of life-preserving system capacities of the planet) i.e. meet the needs of the present generation without damaging the interests of the planet and stopping meet the future generations' needs (Tashakkori, 1996: 2).

3. A definition with a broader view defines sustainable development as "a kind of human activity that explicitly strengthens and sustains the survival of all species of life on the planet throughout history" (Bossel, 2002: 36).

4. The World Bank defines sustainable development as "a development that will last (Leman \& Cox, 1991) also define sustainable development as follows: "The development of sustainable outcomes is a process that aims at improving economic, social, cultural and technological conditions for social justice and not contaminating the ecosystem and degrading natural resources (Azizi, 2001:22)

Development experts enumerate sustainable development policies in four fundamental following pillars:

1- Minimizing the use of non- renewable natural resources (such as fossil fuels and sufficient resources).

2- Sustain the use of non-renewable natural resources (such as groundwater, plant soil).

3- Keeping the limits of production of waste and contaminants in the amount of local and global capture and absorption (such as greenhouse gases, ozone-destructive chemical materials and toxic waste).

4- Providing basic human and social needs (such as access to livelihood tools, the right to choose, participating in determining social status and access to a healthy environment and basic services) (Ziyari2001: 374)

\section{Sustainable Development Indexes}

According to extensive studies in the field of the sustainable development indices' classification has been examined based on quantitative and qualitative criteria.

1) Political index: The effect of political changes, according to Dr. Nooriyan, in the development of cities is the hallmark of urbanization. Participation is a way of managing urban affairs, inventing new methods of consultation with the people, decentralization of management and decision-making, division of large cities to smaller communities and design new forms of governance in major cities and urban regions (Nooriyan, 2000:96).

2) Sociocultural indexes: Socio-cultural development is a long time effort. The development programs in the world are divided in three important aspects that the culture is the most important aspect. The development process is presented as a solution and cultural planning helps realize the goal. The dynamics of urban development means a close relationship between cultural development and its integral part that physical life without cultural development will be unbalanced. Here a part of social-cultural criteria are referred that is considered by the world's urban population: population density, average education and the percentage of qualified personnel, the incidence of poverty, unemployment, crime index growth rate, changing consumption patterns over the period, energy consumption index, the rate of traffic growth, the demand for theaters, cinemas, museums and music, the number of religious and cultural centers, the percentage of access to urban service and the movement (Nooriyan et al). 
3) Economic index: capabilities of cities for the growth and development. Economic development and prosperity is along with the increase in urban development studies (Kazemi, 2001, p. 65) that below a number of its criteria are referred: urban management budget, income distribution among different social classes of citizens per capita income, inflation of investment and attract foreign capital and experts, GDP, and the distribution of economic activities according to services, manufacturing, industry and commerce and etc.

4) Technological index: Quoted by Dr. Ghadimi, the issue of information technology in urban development management is a relatively new and unknown issue. The cause of many problems in the management and planning of urban development has been lack of understanding of the status quo cities, confusion, fragmentation and lack of coordination in collecting information. Basic information about land, real estate, infrastructure, environmental status of the city and access are considered as important criteria for cities' decision-making (Ghadimi, 2000, p. 15).

5) Environmental index: Quoted by Dr. Movahed, the relationship between the city (as an ecological unit) and the human and environment is derived from the time and place. That means that limited understanding of the natural environment and the use of technology in communities, the nature prevail the human. What is emphasized is the balance of the relationship between the human and nature so that no one is subdued by the other. The human progress by access to technological advances has caused environmental adverse consequences. In this discussion, the human performance vs. the nature has been considered that makes the potential of environmental hazard possible. Excessive concentration of the human in big cities, high consumption of resources and consequently attract resources towards themselves to respond to the population in the big cities have been related to environmental issues. The most important needs include: Energy, food and water that excessive use of the data in urban areas will bring output as environmental impact as changes in weather, thermal pollution, water pollution, noise pollution, soil and air pollution and so on.

\section{Ecotourism}

Ecotourism is the abbreviation of the phrase environmental tourism that is a relatively new trend and phenomenon in the tourism industry that constitutes a part of it (Jahanian et al). The definition provided by the National Institute of Ecotourism Australia is: Ecotourism is a form of tourism that is combined with education and awareness of the natural environment and is managed in a way that is ecologically sustainable (Niyazmand, 2001). On the other hand, sustainability in its broad sense is referred to the ability of the community, ecosystem or any current system to continue to function in unlimited future that the concept of the sustainable development means combining economic, social and environmental goals to maximize the current human well-being without damaging the next generations' ability to meet their needs (OECD, 2011, p.11).

By studying, the important indices expressed as related to ecotourism are as follows:

A) Scientific: Understanding and attention to the natural capacity of ecosystems to 
ensure better protection of optimized sustainable reconstruction and production; protection of natural, cultural and religious heritage in tourism areas, heritage value through notification; culture and permanent training to local people and communities, as well as tourists.

B) Social: Recognition and respect for the important role of local people and communities and market them in decision-making, planning and implementation of projects; respect for social, cultural and traditional structures, customs and way of life of local people and communities; respect for the life needs of local people and communities and their dependence on the forest, watersheds and forest resources, positive cultural exchange between tourists and local people and communities and promote the culture of protection of natural and cultural heritage among visitor and host tourists, and enhance the quality of life and scientific awareness of local people and communities.

C) Economic: income for local people and communities and a fair division of revenues; assigning a share of the revenue for the conservation and management of heritage (Jahanian et al).

Azerbaijan is located in northwestern Iran and at the confluence of Alborz and Zagros mountains and is mainly mountainous. Azerbaijani rivers are most in Orumiyeh Lake Watershed and the Caspian Sea. The weather of west and north-west regions of Azerbaijan is Mediterranean and in southern parts is Mediterranean with hot summer. Being on Europe path gives this area a special strategic position.

\section{Conclusion}

By studying and reviewing ecotourism concepts and its effect on the sustainable development, then the current status of Azerbaijan. Iran has been examined as the study of Vegetation, hunting ban, mountains and ski resorts, and finally using the assessment and analysis of SWOT Table.

Table 1:

\begin{tabular}{|c|c|c|c|}
\hline \multicolumn{4}{|c|}{ Vegetation and Pasture in Azerbaijan } \\
\hline Strength & Weakness & Opportunity & Threat \\
\hline $\begin{array}{l}\text { 1. Reducing the volume } \\
\text { of natural resources by } \\
\text { overgrazing of livestock } \\
\text { 2. Development of } \\
\text { agriculture industry } \\
\text { 3. The limited water } \\
\text { resources } \\
\text { 4. Severe soil erosion } \\
\text { and degradation of the } \\
\text { pasture and vegetation } \\
\text { 5. Land dependence on } \\
\text { unauthorized wells } \\
\text { 6. The formation of } \\
\text { consecutive droughts, } \\
\text { desertification and salt } \\
\text { marsh due to the effects }\end{array}$ & $\begin{array}{l}\text { 1. The presence of } \\
\text { beautiful landscapes } \\
\text { to attract tourists } \\
\text { 2. Favorable climate } \\
\text { for the development } \\
\text { of gardens } \\
\text { 3. High extent of the } \\
\text { pasture for livestock } \\
\text { development } \\
\text { 4. No need for } \\
\text { massive investments } \\
\text { to attract young force } \\
5 \text {. The possibility to } \\
\text { create ecotourism } \\
\text { tours } \\
6 . \text { Increased levels of }\end{array}$ & $\begin{array}{l}\text { 1. The lack of drinking } \\
\text { water in the village } \\
\text { 2. The increase of the } \\
\text { village area, lack of } \\
\text { supervision of } \\
\text { construction } \\
\text { 3. An increase in rural to } \\
\text { urban migration } \\
\text { 4. The lack of } \\
\text { infrastructure in } \\
\text { agriculture and trade and } \\
\text { lack of proper minerals' } \\
\text { transfer path } \\
\text { 5. Lack of human and } \\
\text { low-income force } \\
\text { 6. The high rate of }\end{array}$ & $\begin{array}{l}\text { 1. The existence of } \\
\text { diverse vegetation as } \\
\text { pasture and } \\
\text { agriculture } \\
\text { 2. Having a proper } \\
\text { position in the } \\
\text { production of some } \\
\text { crops and livestock } \\
\text { 3. The presence of a } \\
\text { good climate in all } \\
\text { seasons } \\
\text { 4. High ability to } \\
\text { create jobs } \\
\text { 5. Richness in terms } \\
\text { of potential and } \\
\text { mineral resources. }\end{array}$ \\
\hline
\end{tabular}




\begin{tabular}{|c|c|c|c|}
\hline $\begin{array}{l}\text { of climate change and } \\
\text { lack of water resources } \\
\text { 8. The risk of potential } \\
\text { fields due to excessive } \\
\text { use of aquifers } \\
\text { 9. The lack of } \\
\text { knowledge, culture of } \\
\text { tourism and cultural } \\
\text { differences between the } \\
\text { local community and } \\
\text { tourists } \\
\text { 10. Officials' inattention } \\
\text { to solve the problem of } \\
\text { lack of water resources }\end{array}$ & $\begin{array}{l}\text { product for } \\
\text { prosperity and } \\
\text { reducing } \\
\text { unemployment } \\
\text { 7. Planting crops with } \\
\text { low water for } \\
\text { agricultural sector } \\
\text { prosperity with a } \\
\text { reasonable budget }\end{array}$ & $\begin{array}{l}\text { unemployment and low } \\
\text { interest of young rural } \\
\text { people in agricultural } \\
\text { activities } \\
\text { 7. Lack of access to } \\
\text { proper financial resources } \\
\text { for small units } \\
\text { 8. The lack of local } \\
\text { expertise and financial } \\
\text { facilities } \\
\text { 9. Underdevelopment of } \\
\text { the city and lack of living } \\
\text { adequate income } \\
\text { 10. The absence of culture } \\
\text { and adequate training } \\
\text { 11. The lack of sufficient } \\
\text { knowledge to control the } \\
\text { overgrazing of cattle }\end{array}$ & $\begin{array}{l}\text { 6. The natural } \\
\text { features of } \\
\text { geomorphology and } \\
\text { location } \\
\text { 7. The surplus } \\
\text { production of crops } \\
\text { and garden products } \\
\text { for export } \\
\text { 8. The presence of } \\
\text { natural and historical } \\
\text { attractions (cultural } \\
\text { heritage) } \\
\text { 9. The most } \\
\text { important and } \\
\text { beautiful area of } \\
\text { ecotourism } \\
\text { 10. Appropriate } \\
\text { rainfall in all seasons } \\
\text { 11. The Department } \\
\text { of Environment } \\
\text { Protected Areas }\end{array}$ \\
\hline
\end{tabular}

Strength: In reviewing the Table, Azerbaijani region's strengths can be varied vegetation, favorable climate for agriculture and animal husbandry, the existence of favorable grounds for tourism, historical attractions and job opportunities for residents. Therefore, this region has multiple factors and an ideal location for ecotourism activities. The main part of green areas like forests Arasbaran (registered by UNESCO) as protected and hunting ban areas have been supported by relevant organizations.

Weakness: In reviewing the Table, weaknesses can be water shortages, low level of education and culture in environmental fields, the lack of management, high rate of unemployment of residents and lack of youth interest in work, finally increasing migration and underdevelopment in these sectors. On the other hand, shortages of infrastructure, not using appropriate equipment and tools, inattention of related officials and organizations and inappropriate projects without assessing ecotourism capability are important risk factors in the region.

Opportunity: Looking at Table 1, existing opportunities in Azerbaijan region can be activating tourism sector to attract tourists, boost better agriculture, animal husbandry and the economy as an opportunity to boost exports and create jobs of natives. Of course, Azerbaijan region due to the existence of unique nature especially in Arasbaran regions can create an opportunity for tourists' presence, educational and recreational campaigns and using natural energy for investment and productivity of profitability.

Threat: Looking at Azerbaijan region vegetation, what is always threatened in Azerbaijan region can be water, low residents' awareness of the region potential area, limited water resources due to the development and use of traditional agricultural systems, drill unauthorized water wells that have caused drought in recent years. On the other hand, excessive grazing of livestock has caused the pasture degradation and soil erosion. All these cases are related to the lack of knowledge and culture of the beneficiaries and 
officials' inattention for implementing their promises in the region.

Table2:

\begin{tabular}{|c|c|c|c|}
\hline \multicolumn{4}{|c|}{ Wild life and prohibited hunting area } \\
\hline Strength & Weakness & Opportunity & Threat \\
\hline $\begin{array}{l}\text { 1. The risk of } \\
\text { animals' extinction } \\
\text { due to the native } \\
\text { population increase } \\
\text { 2. Hilly habitat } \\
\text { destruction and } \\
\text { conversion to } \\
\text { agricultural land } \\
\text { 3. An increase in } \\
\text { hunting animals in } \\
\text { terms of co-border } \\
\text { and allowance of } \\
\text { carry guns } \\
\text { 4. The human access } \\
\text { to technology and } \\
\text { facilities }\end{array}$ & $\begin{array}{l}\text { 1. Appropriate culture of } \\
\text { people to care for } \\
\text { endangered wildlife } \\
\text { 2. Reduce indiscriminate } \\
\text { hunting to increase the } \\
\text { population of animal and } \\
\text { aquaculture } \\
\text { 3. Animal and vegetable } \\
\text { products for export } \\
\text { 4. The presence of Artemia } \\
\text { (single-cell) as a suitable } \\
\text { food source for native and } \\
\text { migratory birds with high } \\
\text { value of export }\end{array}$ & $\begin{array}{l}\text { 1. Illegal hunting } \\
\text { 2. Inattention of } \\
\text { officials, guards of the } \\
\text { environment and } \\
\text { continued hunting } \\
\text { 3. The indiscriminate } \\
\text { use of water resources } \\
\text { leading to animals' } \\
\text { death }\end{array}$ & $\begin{array}{l}\text { 1. The existence of } \\
\text { wildlife habitats, } \\
\text { livestock herders' } \\
\text { pasture and } \\
\text { waterfowl } \\
\text { 2. The existence of } \\
\text { different species of } \\
\text { mammals, reptiles, } \\
\text { amphibians and } \\
\text { aquatic } \\
\text { 3. The existence of } \\
\text { wildlife migration } \\
\text { corridor at local and } \\
\text { national levels. } \\
\text { 4. The existence of } \\
\text { the largest natural } \\
\text { habitat of Artemia in } \\
\text { the world. } \\
\text { 5. The existence of } \\
\text { tourism and } \\
\text { protected areas of } \\
\text { Wildlife of the } \\
\text { country. }\end{array}$ \\
\hline
\end{tabular}

Strength: What has been considered in reviewing strengths in Table 2 was topography and favorable weather conditions for the creation of important plant and animal habitats that the regions in turn have played an important role as biosphere to prevent the extinction process of animals' generation and wildlife migration corridor as said by UNESCO.

Weakness: The weakness and factors influencing the reduction of existing animal species according to Table 2 have been illegal hunting, officials' inattention, licensing for hunting in hunting ban areas and certain seasons that the reduction of water resources and the limitation are important factors in its destruction and animal species' extinction.

Opportunity: With a glance at Table 2, existing opportunities for a variety of different species of animals and plants can be mentioned in holding international conferences and seminars aimed to promote the culture of natives and officials' deal with unlicensed hunters to avoid indiscriminate hunting. In addition, protection and conservation of existing resources and animal and plant products and will provide an opportunity for domestic and foreign export. On the one hand, the transfer of some rare animal and plant species can prevent the extinction of the species' generation.

Threat: By reviewing hunting ban areas and Table 2, major causes of threatening animal species have been the advancement of technology and human access to facilities as well 
as population growth rate is an important factor in the destruction of biological regions and plant and animal species. This has been reflected by changes in the land use and convert original land to exploitable regions in the present time.

Table 3:

\section{Mountains and Ski Resorts}

\begin{tabular}{|c|c|c|c|}
\hline \begin{tabular}{|l|} 
Strength \\
\end{tabular} & Weakness & Opportunity & Threat \\
\hline $\begin{array}{l}\text { 1. The lack of facilities' } \\
\text { development, inadequate } \\
\text { tools and physical risks for } \\
\text { the users } \\
\text { 2. Reduce the number of } \\
\text { athletes due to the lack of } \\
\text { adequate services and } \\
\text { infrastructure } \\
\text { 3. The lack of needed } \\
\text { water resources for } \\
\text { agriculture as a factor of } \\
\text { migrate to cities } \\
\text { 4. The lack of funding } \\
\text { necessary in order to fence } \\
\text { lands and illegal } \\
\text { exploitation for } \\
\text { agricultural purposes } \\
\text { within the official resort } \\
\text { (in the non-winter } \\
\text { seasons) }\end{array}$ & $\begin{array}{l}\text { 1. The presence of } \\
\text { favorable climate and } \\
\text { ski resorts to attract } \\
\text { tourists } \\
\text { 2. Mountainous area to } \\
\text { attract winter sports' } \\
\text { fans to the centers (ski } \\
\text { resorts) } \\
\text { 3. The existence of } \\
\text { much potential to } \\
\text { attract professionals } \\
\text { 4. The existence of } \\
\text { natural landscapes and } \\
\text { historic sites to attract } \\
\text { tourists and boost } \\
\text { agriculture } \\
\text { 5. The possibility to } \\
\text { create rural } \\
\text { employment and } \\
\text { development socially } \\
\text { and culturally with } \\
\text { urban services and } \\
\text { facilities }\end{array}$ & $\begin{array}{l}\text { 1. Officials' inattention } \\
\text { to deal with the status } \\
\text { of ski resorts of the } \\
\text { province } \\
2 \text {. The lack of } \\
\text { sufficient budget, } \\
\text { financial constraints } \\
\text { and lack of investment } \\
\text { in the creation of } \\
\text { recreational facilities } \\
\text { 3. Narrow and } \\
\text { inadequate the main } \\
\text { road of the entrance } \\
\text { and exit during } \\
\text { disasters } \\
\text { 4. The lack of services } \\
\text { and facilities available } \\
\text { at ski resorts }\end{array}$ & $\begin{array}{l}\text { 1. The existence of } \\
\text { heritage and a belt of } \\
\text { green and beautiful } \\
\text { gardens. } \\
\text { 2. Having unique } \\
\text { natural characteristics } \\
\text { and tourism potential } \\
\text { 3. The existence of } \\
\text { favorable mild } \\
\text { climate in all seasons } \\
\text { (ski resorts) } \\
\text { 4. The existence of } \\
\text { the largest } \\
\text { northwestern ski } \\
\text { resort in the country } \\
\text { registered by Ski } \\
\text { Federation }\end{array}$ \\
\hline
\end{tabular}

Strength: The most obvious strengths of mountainous regions and mountains according to Table 3 are favorable climate for winter sports in the ski resorts that are always considered by eco-tourists and tourists. Also, the historical remains in Azerbaijan Mountains that in turn reflect the cultural heritage of the territory along with natural beautiful regions have been another factor of enhancing ecotourism industry as well as the local economy.

Weakness: According to Table 3, despite the enormous potentials in mountainous regions and mountains of Azerbaijan, officials' inattention, the lack of sufficient budget for investment and the creation of recreational facilities and the lack of services and adequate infrastructure facilities as well as the lack of equipment applied for roads, the lack of on time prediction and driving accidents are considered as the most fundamental factors weakening these areas.

Opportunity: By reviewing Table 3 and mountainous areas, favorable weather in cold seasons of the year and prolonged rainfall provide the possibility of attracting domestic and foreign tourists. On the one hand, winter sports are developed by attracting qualified personnel. On the other hand, the existence of mines and potential lied in the heart of 
the mountains and natural beautiful regions not only provide natives' economy but also attract tourists and introduce the beauty of these regions.

Threat: The lack of facilities' development and adequate infrastructure in winter and in mountainous regions and highlands according to Table 3 not only cause the reduction in attracting tourists but also life-threatening risks for tourists. On the other hand, the lack of understanding and exploiting of the situations in the region by residents, resort land conversion to agricultural regions, illegal exploitation, the destruction of the natural environment and migrating tribes to cities due to the lack of resources are factors affecting the destruction of resources.

Table 4:

\section{Rivers, Lakes and Lagoons}

\begin{tabular}{|c|c|c|c|}
\hline trength & Weakness & Opportunity & Threat \\
\hline $\begin{array}{l}\text { 1. The lack of continuity of } \\
\text { water resources to future } \\
\text { generations as a result of the } \\
\text { unsustainable development } \\
\text { 2. Habitats' destruction with } \\
\text { the formation of the } \\
\text { environmental crisis } \\
\text { 2. The lack of the possibility } \\
\text { of irrigation and water } \\
\text { supply due to lack of rainfall } \\
\text { 3. Construction of the } \\
\text { aquaculture workshops as a } \\
\text { factor of the land } \\
\text { degradation, desertification } \\
\text { and the land use change } \\
\text { 4. Conflicting with no } \\
\text { economic projects with } \\
\text { commitment to the rational } \\
\text { use of the Lake and other } \\
\text { general rules and principles } \\
\text { of international } \\
\text { environmental law } \\
\text { 5. The destruction of } \\
\text { underground aquifers by } \\
\text { drill wells illegally } \\
\text { 6. Construct dam } \\
\text { 7. Dark future of Urmia } \\
\text { Lake for water resources } \\
\text { with inattention and } \\
\text { continuity of lack of water }\end{array}$ & $\begin{array}{l}\text { 1. The supply of } \\
\text { needed water using } \\
\text { embedded channel to } \\
\text { resolve water } \\
\text { shortage } \\
\text { 2. Fishing for job } \\
\text { creation among } \\
\text { natives } \\
\text { 3. Services (tourism } \\
\text { and ecotourism, hot } \\
\text { springs, mud therapy, } \\
\text { aquaculture and } \\
\text { education, research, } \\
\text { and cultural heritage). } \\
\text { 4. The use of modern } \\
\text { agricultural tools and } \\
\text { methods to conserve } \\
\text { water resources } \\
5 . \text { Construct water } \\
\text { pools for storage and } \\
\text { prevent the } \\
\text { completion of water } \\
\text { resources } \\
6 . \text { The possibility of } \\
\text { creating a targeted } \\
\text { time system to irrigate } \\
\text { gardens around }\end{array}$ & $\begin{array}{l}\text { 1. Migration of natives } \\
\text { due to ecological and } \\
\text { climate changes } \\
\text { 2. The unsustainable } \\
\text { development } \\
\text { 3. The lack of water } \\
\text { and water supply in } \\
\text { the agricultural sector } \\
\text { 4. The river facing } \\
\text { with wastewater of } \\
\text { irrigation canals } \\
\text { 5. Environmental } \\
\text { pollution and drought } \\
\text { due to the lack of } \\
\text { proper management of } \\
\text { water resources } \\
\text { 6. Discontinuity of } \\
\text { water resources to } \\
\text { future generations } \\
\text { 7. The indiscriminate } \\
\text { use of water resources } \\
\text { and aquifers } \\
\text { groundwater } \\
\text { 8. Drill illegal wells } \\
\text { 9. The lack of proper } \\
\text { planning and } \\
\text { management of the } \\
\text { exploitation of water } \\
\text { resources }\end{array}$ & $\begin{array}{l}\text { 1. The variety of } \\
\text { plant and animal } \\
\text { coverage (flora and } \\
\text { fauna) } \\
\text { 2. One of the most } \\
\text { important natural } \\
\text { ecosystems and the } \\
\text { most valuable } \\
\text { ecosystems of the } \\
\text { watershed of Urmia } \\
\text { Lake } \\
\text { 4. High ecological } \\
\text { ability and special } \\
\text { climatic conditions } \\
\text { 5. Tourism } \\
\text { attractions, the } \\
\text { presence of beautiful } \\
\text { stunning landscapes, } \\
\text { unique sites and } \\
\text { positive effect the } \\
\text { ecosystem } \\
\text { 6. The most valuable } \\
\text { ecosystems in Iran } \\
\text { due to having special } \\
\text { ecological conditions } \\
\text { and the wetlands }\end{array}$ \\
\hline
\end{tabular}

Strength: Azerbaijani region contains the most important rare aquatic ecosystems that most of these regions after the vegetation, are covered by water zones. Ecological and environmental characteristics of these regions, high capability of existing habitats in Urmia Lake watershed, waterfowl migration to these regions and establishing the balance 
between ecological and animal cycles are considered as the most important strengths of the regions. Strong dependence and relationship of wetlands around Urmia Lake and the presence of specific climatic conditions of the regions that turn them into protected regions include plant and animal coverage. That the contribution of each of these ecosystems is another important factor to mitigate drought, warmth and ecosystem effects found in these regions.

Weakness: According to Table 4, the lack of water resources, land, groundwater, climate and ecological changes in the regions have significant negative impact on various regions such as natural resources' drought. In addition, climate changes and the lack of proper management by organizations have moved natural and water resources to the destruction. Drill wells illegally and excess in agricultural lands' irrigation are the main causes of lack of water resources and rural to urban migration.

Opportunity: With a glance at Table 4 that represent opportunities such as the existence of hot and cold springs, construction of water pools and tanks to store these resources, using modern tools and methods of agriculture such as targeted time irrigation systems, drip irrigation method and employment in the field of pisciculture is noted.

Threat: What is considered as the main problem in relation to water resources is the lack of water resources and its continuity causing the unsustainable development of water resources, and endangered natural environment and environmental crises that the consequences can be seen in the destruction of animal habitats. Impossibility of irrigation, reduce the quality of agricultural products, thus loss of economic prosperity, the destruction of groundwater aquifers and land use change will affect ecology and economic policy of countries adversely. Consequently, conflicting provisions of economic projects and principles and rules of international law on the use of these resources and Urmia Lake drought will involve Iran's neighboring countries.

\section{Conclusion}

Azerbaijan region in terms of ecology, flora and fauna diversity is a unique region. The strengths of Azerbaijan as mild weather in most seasons and natural-historic attractions have made it as one of the main centers of the region's tourism industry. During recent decades, the decline of the points caused the region's ecological and environmental system problematic, and perhaps it can be said the lack of water crisis especially Urmia Lake, and the lack of proper management program to address this major problem today has caused many concerns for officials and the nature lovers. This problem continuation will cause problems such as drought of natural and agricultural resources, forests' destruction and extinction of species of animals and plants in Iran and in other neighboring countries. In addition, with the loss of this natural beauty, different regions' economy will face serious problems that as a result this will cause rural to urban migration, establishing urbanism philosophy with an emphasis on cities' capabilities in terms of resources and services and little interest in keeping them. On the other hand, the lack of appropriate culture, groundwater aquifers completion, successive droughts and finally soil erosion will occur. Legal hunting protected regions, officials' inattention to follow and solve the problems are other factors of extinction of different animal species and have a significant effect on the destruction of this valuable heritage. 
10. We hope that by implementing proposals on ecotourism potential with the sustainable development view the existing problems can be solved: Using new tools and ways to conserve water resources such as irrigation time targeted system for gardens and farms, the benefit of natural energy in the regions of Azerbaijan such as wind and solar energy for power generation, transmission of extinct species in protected areas to prevent hunting and extinction, planting pistachio to prevent soil erosion around Urmia Lake, serious deal of officials with illegal drilled wells and held tours aimed to become familiar with natural environment and create campaigns for waste collection and help the animals.

\section{References}

Azizi, Mohammad Mehdi (2001). Sustainable Urban Development Sustained and analyzed from Global Perspectives. Soffeh Journal of Research. No.33,pp. 15-27.

Bossel, Hartumut (Translator: Darabi, Hasan) (2000). Sustainable Development: Concepts and Limitations. Quarterly Journal of Housing and Revolution. No.89.

Forslid, R., Haaland, J. I., \& Knarvik, K. H. M. (2002). A U-shaped Europe? : A simulation study of industrial location. Journal of International Economics, 57(2), 273-297.

Gadimi,hojjat allah(2000).The Role of Information Technology in Urban Management and

development. Magezine of the municipalities second year. No. 23, Tehran.

Haji Rahimi, M., Ghaderzadeh, H. (2008). The challenges of Sustainable Management in Renewable Natural Resources in Iran: A SWOT Strenghth. American-Eurasian J. Agric. \& Environ. Sci. 4(6):760-764.

Jahanian, Manuchehr, Zandi, Ebtehal (2013). The Ecotourism. Collection of Tourism, scientific \& Specific books, Jahad University Publication, (Third Edition).

Kazemi Mohammadi, Moosa (2001). Sustainable development of cities: case study: Ghom City. Proceedings of the first sustainable management and sustainable development conference in the urban areas of Tabriz. Pp. 68-79.

Leman, Edward and Cox, John (1991).Sustainable Urban Development: Strategic Consideration for Unbanning Nation. Ekistics. Vol. 348- 349, pp. 216- 224.

Marsuei, Masumeh \& Bahrami, Rahmatollah (2011). Sustainable Development: Book of Tomorrow. Payame noor University Publication (No.7).

Niyazmand, M. (2002). An overview of Ecotourism. Journal of Transportation Industry. No. 216

Nouri,Hedayat allah, Noruzi Avaregani, Asghar,( 2007 ).Environmental Capacity Assessment of Tourism Development in Choghakhor village. Journal of Research in Isfahan University. NO.1(22).

Nooriyan, Farshad (2000). Application of Information Systems in Urban Planning Management in Iran. Urban Management Quarterly (No. 4).

Nyaupane, G.P., and B. Thapa (2004). Evaluation of ecotourism: a comparative assessment in the Annapurna conservation area project. Nepal, Journal of Ecotourism. 3(1), pp. 20-45.

OECD (Organization for Economic Co-operation and development) (2001 a). investing in Competencies for All: Meeting of the OECD Education Ministers, Paris, 3-4 April 2001, OECD, and Paris.

Parham, S.* , Salehi , E. , Maghsudi , M (2011). Ecological Capability of Ecotourism in Isfahan Provice (Case Study: Eshkavand Village and Conurbations). , Environment and Development Journal. 2012(Issue 4).

Sadat M., Karimi, Amiri, MJ. , Zoughi. Evaluation of ecotourism in protected areas, to contribute to sustainable rural development (Case Study: Rural Arasbaran protected area gets torn).

Salami, Reza (1997). Brief overview of sustainable development. Approach No.17, pp.87- 84.

Tuğba Kiper (2013). Role of Ecotourism in Sustainable Development, Advances in Landscape Architecture, Dr. Murat Ozyavuz (Ed.), InTech, DOI: 10.5772/55749. Available from: https://www.intechopen.com/books/advances-in-landscape-architecture/role-of-ecotourism-insustainable- development.

Yang \& Berton, M.P., Translated by: Tashakkori, Mohsen (1996). Agricultural Sustainability: Definition and implication in Trade and Agriculture Policies. Agricultural Economics Planning Research Institute.

Ziyari, Keramatollah (2001). Sustainable Development and Urban Planners Responsibilities in twenty- one century. Journal of Faculty of Literature \& Humanities University of Tehran (No. 160), pp. 371- 385. 